\title{
Socio Economic Upliftment of Rural Fishermen and Poverty Alleviation through Integrated Duck Cum Fish Farming in Purulia District, West Bengal, India
}

\author{
Abhishek Majhi* \\ Department of Economics, Sidho-Kanho-Birsha University, Purulia, West Bengal, India \\ *Corresponding author
}

\begin{tabular}{|l|}
\hline Ke y w o r d s \\
Integrated Farming, \\
Duck cum Fish, \\
Poverty alleviation, \\
Nutritional \\
Security, Rural \\
Fishermen \\
\hline Article Info \\
\hline $\begin{array}{l}\text { Accepted: } \\
\text { 18 May 2020 } \\
\text { Available Online: } \\
\text { 10 June 2020 }\end{array}$ \\
\hline
\end{tabular}

\section{A B S T R A C T}

Integrated fish farming is based on the concept that 'there is no waste', and waste is only a misplaced resource which can become a valuable material for another product. In integrated farming, the basic principles involve the utilization of the synergetic effects of inter-related farm activities and the conservation, including the full utilization of farm wastes. It is assumed that all the constituents of the system would benefit from such a combination. However, in most cases, the main beneficiary is the fishes which utilize the animal and agricultural wastes directly or indirectly as food. As integrated farming involves the recycling of wastes, it has been considered an economic and efficient means of environmental management. The economic benefit of integrated fish farming cannot be over-emphasized since the integration is varied and diversified in nature. It is one of the most viable, reliable and profitable of any farming enterprise. It contributes immensely to the economic empowerment of many families especially in the rural communities. It enables the farmer to be productive all the year round and fully maximize its production. Its contribution in the enhancement of food security and self-sufficiency is highlighted in this study. Integrated fish farming provides the farmer with a steady source of income all year round; this comes from various farm products. In duck-cum fish farming before the harvesting of the fish, which may take some months, the farmer can sell the eggs which will generate money for some time. Apart from this, money can also be generated from the vegetables or the crops that may be combined in the integrated fish farming. This study is based on primary data and conducted during the months of October 2016 to November 2016. To study the socio-economic status of the rural integrated duck cum farmers, a sample of 20 respondents was carved out randomly from the four villages in Purulia-I Block of district Purulia in West Bengal. The generated data were computed and analyzed through statistical tools and overall economic return in terms of productivity of the fishery and duckery practices, their gross return, net return and ultimate B:C ratio. Integrated duck-fish farming has become popular for household nutritional security and women empowerment in the remote villages of Purulia district. Additionally, the consumption of eggs/fish and meat adds to food quality and livelihood security of the resourcepoor family. The study has concluded that the integrated duck-fish system could address issues of sustainability, women empowerment and livelihood security effectively.

\section{Introduction}

The principle of integrated fish farming involves farming of fish along with livestock or/and agricultural crops. This type of farming offers great efficiency in resource utilization, as waste or byproduct from one system is effectively recycled. It also enables effective utilization of available farming space for maximizing production. The rising cost of protein rich fish food and chemical fertilizers as well as the general concern for energy conservation have created awareness in the utilization of rice and other crop fields and 
livestock wastes for fish culture. Integrated fish farming combines livestock production with fish farming. Animal manure is shed directly into a fish pond as fertilizer and supports the growth of photosynthetic organisms. The livestock, mainly duck, chickens and pigs, is often fed feed containing growth promoters. The farming systems are relatively confined units with little exchange of water. Manure from livestock production is administered to fish ponds; the manure is directly consumed by fish, and the release of nutrients supports the growth of mainly photosynthetic organisms.

This integrated fish farming system produces high yields with low input, with the fish receiving limited, if any, supplementary feed. In contrast, the livestock on the integrated farms, which includes duck, chickens and pigs, is reared intensively, and antimicrobial agents are used as growth promoters and for prophylactic and therapeutic treatment. Within integrated fish farming systems, antimicrobials, their residues, and antimicrobial-resistant bacteria may enter the fish ponds through animal manure and/or excess feeding and are potential sources of antimicrobial-resistant bacteria.

The raising of ducks over fish ponds fits very well with the fish poly culture as ducks are highly compatible with cultivated fish The ducks feed on such organisms from the pond as larvae of aquatic insects tadpoles, mollusks, aquatic weeds etc. which do not form the food of stocked fish. The duck droppings act as excellent pond fertilizer and the dabbling of ducks at the pond bottom in search of food, releases, and nutrients from the soil which enhances the pond productivity and consequently increases fish production.

The ducks in turn get clean and healthy environment to live and quality natural food from the pond for their growth. The technique of combining fish culture and duck raising in
Indian conditions has been developed and demonstrated by the Operational Research Project of this Institute.

By this method it has been possible to attain fish production ranging from 3500-4000 $\mathrm{kg} / \mathrm{ha} / \mathrm{yr}$ from the ponds of the farmers in West Bengal without resorting to supplementary feeding.

Fish utilizes the feed spilled by ducks and eat their droppings directly by some fishes. Ducks increases the pond productivity by releasing the nutrients from the pond bottom soil through dabbling the pond bottom mud. From the same places at the same time duck meat \& eggs and also the fish can be produced. Duck get $50-75 \%$ of their total feed requirement from the pond itself in the form of aquatic weeds, insects, mollusks, etc. which do not form the food of the fish. Duck dropping contains $81 \%$ water, $0.91 \%$ nitrogen and $0.38 \%$ phosphorous.

Dicks are given free range from 9 a.m. to 5 p.m. in the pond and the excreta released during this period are easily mixed with pond water and fertilize it. Again duck droppings voided during night at the duck house are collected and applied to the fish pond in the morning hours to fertilize the pond water. Dick dropping act as a good fertilizer which helps in producing fish feed i.e. phytoplankton \& zooplankton in fish pond. So application of extra fertilizer and feed to fish pond for raising fish is not needed. This cuts the cost of fish production by $60 \%$. One duck voided about 125-150 gms. excreta in a day.

Therefore by stocking 250- 300 ducklings/ ha (30- 40 ducklings/ bigha) water spread area the required quantity of duck excreta, i.e. $10000-15000 \mathrm{~kg} /$ year / ha $(1300-2000 \mathrm{~kg} /$ year/ bigha water spread area) can be received. When phytoplanktonic bloom is seen over the surface water of fish pond then application of duck droppings to the pond should immediately be suspended. The 
adoption of integrated duck cum fish farming can offer opportunities for livelihood and food security to the households of the Purulia district. Keeping this in view, the present study has been conducted to assess the economics of prevailing duck production systems and their role in ensuring rural livelihood security and sustainability in the Purulia district of west Bengal.

\section{Materials and Methods}

The present study is based on an intensive fieldwork conducted in Purulia-I Block of Purulia district, West Bengal during the months of October 2016 to November 2016. Before the commencement of fieldwork, a pilot study was conducted during the month of September 2016. Based on that pilot study, Purulia-I Block of Purulia district were selected for final study. Purposive sampling method was used while selecting the study area. Physiographically, Purulia, the westernmost district of West Bengal, is well known as a drought prone district and falls within the semi-arid region of the state. Cultivation of this district is predominantly mono-cropped. Out of total geographical land $52.47 \%$ are used for agriculture. $29.69 \%$ are under forest coverage (including social forestry) and $10.15 \%$ are identified as Wasteland. Soil erosion is the most prominent phenomenon of the district resulting huge deposition of fertile soil in the valley region.

Vast areas of land remained uncultivable wasteland. Out of the total agricultural holding about $73 \%$ belongs to small and marginal farmers having scattered and fragmented smallholding. About $90 \%$ of the population lives in villages and about $44 \%$ of the rural population is below poverty line. The three main advantages of sampling are that the cost is lower, data collection is faster, and since the data set is smaller it is possible to ensure homogeneity and to improve the accuracy and quality of the data. Sampling is concerned with the selection of a subset of individuals from within a population to estimate characteristics of the whole population which is homogeneous in nature. Sampling is the process of selecting units likes people, organizations from a population of interest so that by studying the sample we may fairly generalize our results back to the population from which they were chosen. Using random sampling method around 20 Rural Integrated Duck cum Fish Farmer were selected for final study.

\section{Results and Discussion}

From (Table-1), it clearly indicates that the maximum percentage of Integrated Duck cum Fish Farmers in Purulia-I block were within medium age group (i.e. between the age group 30 to 40 years), while $20 \%$ Farmers age were below 30 years only, followed by $20 \%$ were 41-50 age group, 20\% were 51-60 age group and only 5\% Farmers were above 60 years age group. From the ensuing results it can therefore be concluded that the majority of the workforce participating in the study is fairly young.

In the present study area it was evident that the literacy level of Integrated Farmers are very poor. From (table-2) it clearly indicates the major percentage $(40 \%)$ farmers are educated upto primary level, while $20 \%$ farmers are Illiterate, followed by $25 \%$ are educated upto upper primary level. Whereas a considerable numbers of Integrated Farmers having education upto madhyamik (10\%) and higher secondary level (5\%). This clearly shows that the literacy rates of this area are really poor and miserable. In the present study Caste category of the respondent shown in table 3 , which depict the majority (50 percent) of Integrated duck cum fish farmers belonging to Schedule Tribe category, remaining $30 \%$ famers belonging to Schedule Caste category whereas $15 \%$ farmers were General caste and only $10 \%$ were Other caste. 
Table-4 present the percentage of gender distribution of the sample. The sample was representative of a larger number of male respondents to that of female respondents. Male respondents comprised of $100 \%$ compared to $00 \%$ female respondents. From the ensuing results it can therefore be concluded that the male responds are more interested in this job than female responds. Table-5 present the percentage of marital status of the respond. The sample was representative of a larger number of married respondents to that of unmarried respondents. Married respondents comprised of $90 \%$ compared to $10 \%$ unmarried respondents. This study illustrates that the maximum percentage $(60 \%)$ of Integrated Duck cum Fish Farmers in Purulia-I block having Nuclear family type whereas $40 \%$ Integrated Duck cum Fish Farmers having Joint family type.

From the above table it is very clear that $50 \%$ respondents have pure kaccha houses to dwell in, whereas $35 \%$ respondents do have semipakka houses, while only $15 \%$ respondents have pakka houses. Since they live in most of the villages have been situated in the remote, rural, and forest areas, so the people are forced to live in the kaccha houses. To construct a pakka house, there are plenty of problems. All farmers are distributed in accordance with the subsidiary and a casual occupation since Pisciculture is main occupation. In every household, some of the members are involved full time in Pisciculture whereas others expense part time by practicing subsidiary and casual occupations as shown in the table. The data exhibited that majority of Integrated Duck cum Fish Farmers in Purulia-I block are engaged in Pisciculture activities (50 percent), followed by Pisciculture and Agriculture (30 percent), Pisciculture and Business (10 percent), Pisciculture and Labour (10 percent) as a subsidiary occupation. Integrated farming is a sustainable and effective tool for improving rural economy due to its cumulative cost effectiveness, low investment and higher profitability. To achieve optimum production with cost effective low investment recycling of wastes and residues from one farming to other system with due environmental consideration is very much necessary. Sustainable integrated farming practice is a very good option. This is a viable option for augmenting overall farm productivity and better economic return of rural pond based farming community.

From table 9, it clearly indicate that in case of Traditional Pisciculture the average Investment, Income and Profit were Rupees 34210/-, Rupees 54325/- and Rupees 20015/respectively. On the other hand in case of Integrated Duck cum Fish Farming the average Investment, Income and Profit were Rupees 53560/-, Rupees 82950/- and Rupees 29290/- respectively. The economic benefit of integrated fish farming cannot be overemphasized since the integration is varied and diversified in nature. It is one of the most viable, reliable and profitable of any farming enterprise.

It contributes immensely to the economic empowerment of many families especially in the rural communities. It enables the farmer to be productive all the year round and fully maximize its production. Its contribution in the enhancement of food security and selfsufficiency is highlighted in this study. Integrated fish farming provides the farmer with a steady source of income all year round; this comes from various farm products. In duck-cum fish farming before the harvesting of the fish, which may take some months, the farmer can sell the eggs which will generate money for some time. Apart from this, money can also be generated from the vegetables or the crops that may be combined in the integrated fish farming. 
Table.1 Age Distribution of the Integrated Duck cum Fish Farmers of Purulia-I block in Purulia District

\begin{tabular}{|c|c|c|c|c|c|c|}
\hline Age (Years) & $<\mathbf{3 0}$ & $\mathbf{3 0 - 4 0}$ & $\mathbf{4 1 - 5 0}$ & $\mathbf{5 1 - 6 0}$ & $\mathbf{6 0}$ & Total \\
\hline Villages & & & & & & \\
\hline Shibdih & 1 & 2 & 1 & 1 & 0 & 5 \\
\hline Ramnagar & 0 & 2 & 1 & 1 & 1 & 5 \\
\hline Fatepur & 1 & 1 & 2 & 1 & 0 & 5 \\
\hline $\begin{array}{c}\text { Ralibera } \\
\text { Total with \% } \\
\text { Involved }\end{array}$ & $4(20 \%)$ & $7(35 \%)$ & $4(20 \%)$ & $4(20 \%)$ & $1(5 \%)$ & $20(100 \%)$ \\
\hline
\end{tabular}

Table.2 Distribution of the Education Qualification level of the Integrated Duck cum Fish Farmers of Purulia-I block in Purulia District

\begin{tabular}{|c|c|c|c|c|c|c|}
\hline Edu. Level & Illiterate & $\begin{array}{c}\text { Class IV } \\
\text { Pass }\end{array}$ & $\begin{array}{c}\text { Class } \\
\text { VIII } \\
\text { Pass }\end{array}$ & $\begin{array}{c}\text { Madhyamik } \\
\text { Pass }\end{array}$ & $\begin{array}{c}\text { H.S. } \\
\text { Pass }\end{array}$ & Total \\
\hline Villages & 1 & 2 & 2 & 0 & 0 & 5 \\
\hline Shibdih & 0 & 2 & 1 & 1 & 1 & 5 \\
\hline Famnagar & 1 & 1 & 2 & 1 & 0 & 5 \\
\hline Ratepur & 2 & 3 & 0 & 0 & 0 & 5 \\
\hline $\begin{array}{c}\text { Total with \% } \\
\text { Involved }\end{array}$ & $4(20 \%)$ & $8(40 \%)$ & $5(25 \%)$ & $2(10 \%)$ & $1(5 \%)$ & $20(100 \%)$ \\
\hline
\end{tabular}

Table.3 Caste of the Integrated Duck cum Fish Farmers of Purulia-I block in Purulia District

\begin{tabular}{|c|c|c|c|c|c|}
\hline Caste & General & SC & ST & Others & Total \\
\hline Villages & & & & & \\
\hline Shibdih & 2 & 1 & 1 & 1 & 5 \\
\hline Ramnagar & 1 & 2 & 1 & 1 & 5 \\
\hline Fatepur & 0 & 2 & 3 & 0 & 5 \\
\hline Ralibera & 0 & 1 & 4 & 0 & $20(100 \%)$ \\
\hline Total with \% Involved & $3(15 \%)$ & $6(30 \%)$ & $9(45 \%)$ & $2(10 \%)$ & \\
\hline
\end{tabular}

Table.4 Gender of the Integrated Duck cum Fish Farmers of Purulia-I block in Purulia District

\begin{tabular}{|c|c|c|c|}
\hline Gender & Male & Female & Total \\
\hline Villages & & & 5 \\
\hline Shibdih & 5 & 0 & 5 \\
\hline Ramnagar & 5 & 0 & 5 \\
\hline Fatepur & 5 & 0 & 5 \\
\hline Ralibera & 5 & 0 & $20(100 \%)$ \\
\hline
\end{tabular}


Table.5 Marital Status of the Integrated Duck cum Fish Farmers of Purulia-I block in Purulia District

\begin{tabular}{|c|c|c|c|}
\hline Marital Status & Married & Unmarried & Total \\
\hline Villages & & & 5 \\
\hline Shibdih & 4 & 1 & 5 \\
\hline Ramnagar & 5 & 0 & 5 \\
\hline Ratepur & 4 & 1 & 5 \\
\hline Total with \% Involved & 18 & 0 & $20(100 \%)$ \\
\hline
\end{tabular}

Table.6 Distribution of Integrated Duck cum Fish Farmers according to family type of Purulia-I block in Purulia District

\begin{tabular}{|c|c|c|c|}
\hline Family Type & Joint & Nuclear & Total \\
\hline Villages & & & 5 \\
\hline Shibdih & & 3 & 5 \\
\hline Ramnagar & 2 & 5 & 5 \\
\hline Fatepur & 0 & 3 & 5 \\
\hline Ralibera & 2 & 1 & $20(100 \%)$ \\
\hline
\end{tabular}

Table.7 Nature of House of the Integrated Duck cum Fish Farmers of Purulia-I block in Purulia District

\begin{tabular}{|c|c|c|c|c|}
\hline $\begin{array}{c}\text { Nattre of House } \\
\text { Villages }\end{array}$ & Kaccha & Semi- Pakka & Pakka & Total \\
\hline Shibdih & & & & 5 \\
\hline Ramnagar & 1 & 2 & 1 & 5 \\
\hline Fatepur & 3 & 3 & 1 & 5 \\
\hline Ralibera & 4 & 1 & 1 & 5 \\
\hline Total with \% Involved & $10(50 \%)$ & $7(35 \%)$ & $3(15 \%)$ & $20(100 \%)$ \\
\hline
\end{tabular}

Table.8 Distribution of Integrated Duck cum Fish Farmers according to different occupation of Purulia-I block in Purulia District

\begin{tabular}{|c|c|c|c|c|c|}
\hline Occupation & Fishery & $\begin{array}{c}\text { Fishery + } \\
\text { Agriculture }\end{array}$ & $\begin{array}{c}\text { Fishery + } \\
\text { Business }\end{array}$ & $\begin{array}{c}\text { Fishery + } \\
\text { Labour }\end{array}$ & Total \\
\hline Villages & & 1 & 0 & 1 & 5 \\
\hline Shibdih & 3 & 2 & 0 & 1 & 5 \\
\hline Ramnagar & 2 & 1 & 2 & 0 & 5 \\
\hline Fatepur & 2 & 2 & 0 & 0 & 5 \\
\hline $\begin{array}{c}\text { Ralibera } \\
\text { Total with \% } \\
\text { Involved }\end{array}$ & $10(50 \%)$ & $6(30 \%)$ & $2(10 \%)$ & $2(10 \%)$ & $20(100 \%)$ \\
\hline
\end{tabular}


Table.9 Average Economics of all Traditional Culture and Integrated Duck cum Fish Farming at Purulia-I Block, Purulia: Schedule Depicted on Average Pond Size of 1 Bigha $\left(1,333.33 \mathrm{~m}^{2}\right)$

\begin{tabular}{|c|c|c|c|c|c|c|}
\hline \multirow[b]{2}{*}{ Farmers No. } & \multicolumn{3}{|c|}{ Traditional Pisciculture } & \multicolumn{3}{|c|}{ Integrated Duck cum Fish farming } \\
\hline & $\begin{array}{c}\text { Investment } \\
\text { (Approx) } \\
\text { (Rs/Yr.) }\end{array}$ & $\begin{array}{c}\text { Income } \\
\text { (Approx) } \\
\text { (Rs/Yr.) }\end{array}$ & $\begin{array}{c}\text { Profit } \\
\text { (Approx) } \\
\text { (Rs/Yr.) }\end{array}$ & $\begin{array}{c}\text { Investment } \\
\text { (Approx) } \\
\text { (Rs/Yr.) }\end{array}$ & $\begin{array}{c}\text { Income } \\
\text { (Approx) } \\
\text { (Rs/Yr.) }\end{array}$ & $\begin{array}{c}\text { Profit } \\
\text { (Approx) } \\
\text { (Rs/Yr.) }\end{array}$ \\
\hline Farmer 1 & 33500 & 52000 & 18500 & 53200 & 81500 & 28300 \\
\hline Farmer 2 & 35700 & 58000 & 22300 & 55000 & 85000 & 30000 \\
\hline Farmer 3 & 30000 & 51000 & 21000 & 53000 & 82000 & 29000 \\
\hline Farmer 4 & 32000 & 50000 & 18000 & 54000 & 88000 & 34000 \\
\hline Farmer 5 & 32500 & 52000 & 19500 & 51000 & 80000 & 29000 \\
\hline Farmer 6 & 37500 & 55000 & 17500 & 56000 & 82000 & 26000 \\
\hline Farmer 7 & 30000 & 51000 & 21000 & 54000 & 85000 & 31000 \\
\hline Farmer 8 & 36000 & 59000 & 23000 & 49000 & 80000 & 31000 \\
\hline Farmer 9 & 31500 & 53000 & 21500 & 60000 & 88000 & 28000 \\
\hline Farmer 10 & 35000 & 53500 & 18500 & 52000 & 80000 & 28000 \\
\hline Farmer 11 & 40000 & 60000 & 20000 & 55000 & 82000 & 27000 \\
\hline Farmer 12 & 38500 & 58000 & 19500 & 51000 & 81500 & 30500 \\
\hline Farmer 13 & 36000 & 57000 & 21000 & 57000 & 85000 & 28000 \\
\hline Farmer 14 & 31000 & 53000 & 22000 & 53000 & 82000 & 29000 \\
\hline Farmer 15 & 35000 & 54000 & 19000 & 52000 & 80000 & 28000 \\
\hline Farmer 16 & 37000 & 51000 & 14000 & 58000 & 85000 & 27000 \\
\hline Farmer 17 & 30000 & 56000 & 26000 & 51000 & 82000 & 29000 \\
\hline Farmer 18 & 35000 & 54000 & 19000 & 50000 & 86000 & 36000 \\
\hline Farmer 19 & 32000 & 49000 & 17000 & 52000 & 81000 & 29000 \\
\hline Farmer 20 & 38000 & 60000 & 22000 & 55000 & 83000 & 28000 \\
\hline $\begin{array}{c}\text { Average } \\
\text { value }\end{array}$ & 34310 & 54325 & 20015 & 53560 & 82950 & 29290 \\
\hline
\end{tabular}

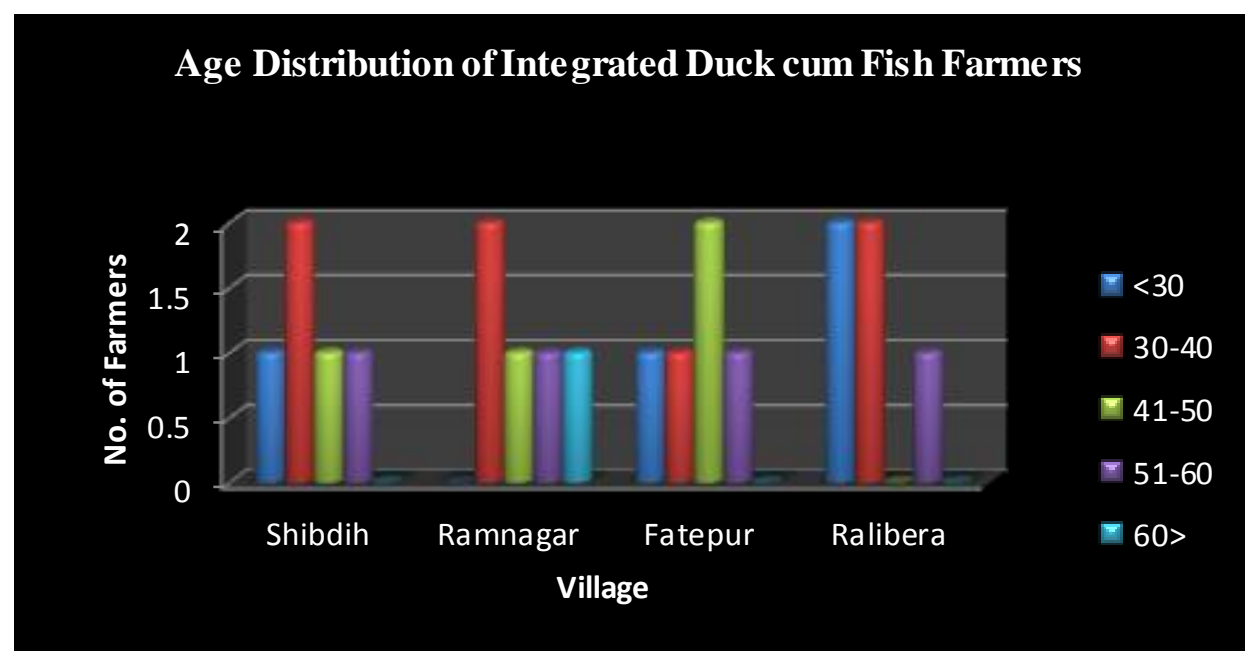

Fig.1 Age Distribution of Integrated Duekeum Fish Farmers 


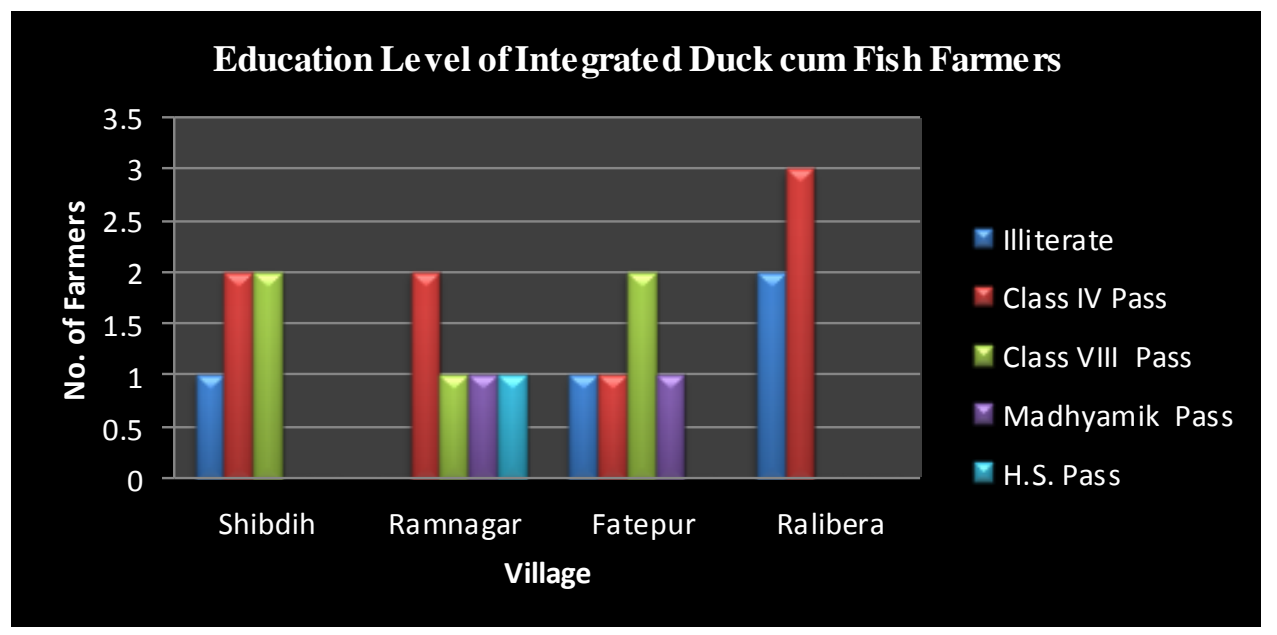

Fig.2 Education level of integrated Duck cum fish farmers

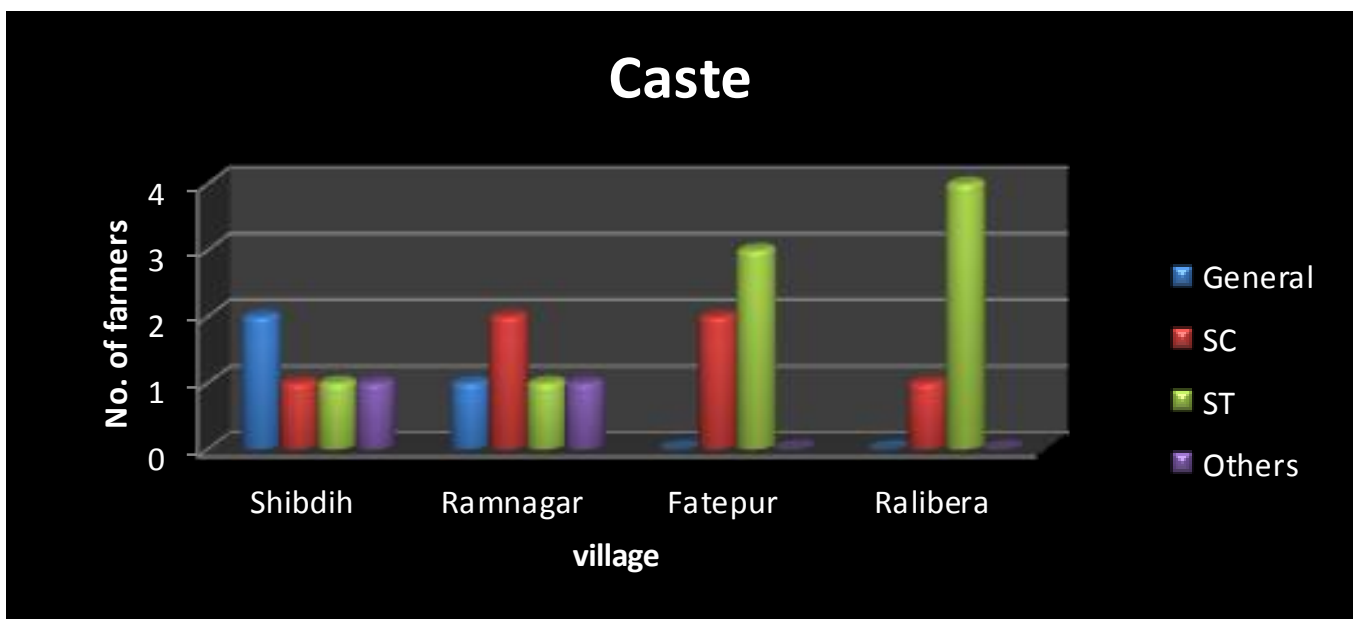

Fig.3 Caste

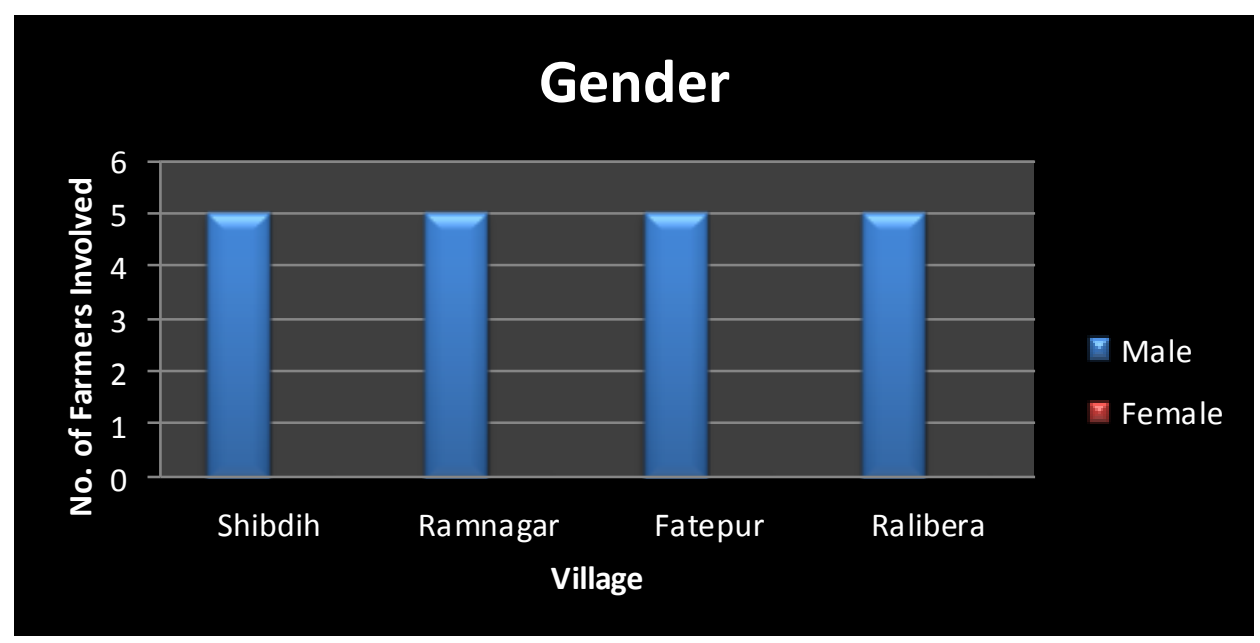

Fig.4 Gender 


\section{Marital Status}

$10 \%$

Fig.5 Marital Status

\section{Family Type}

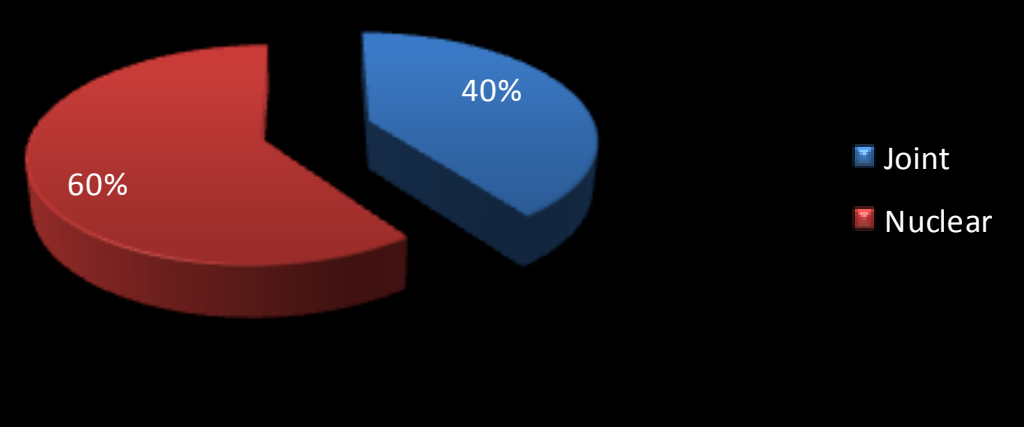

Fig.6 Family type

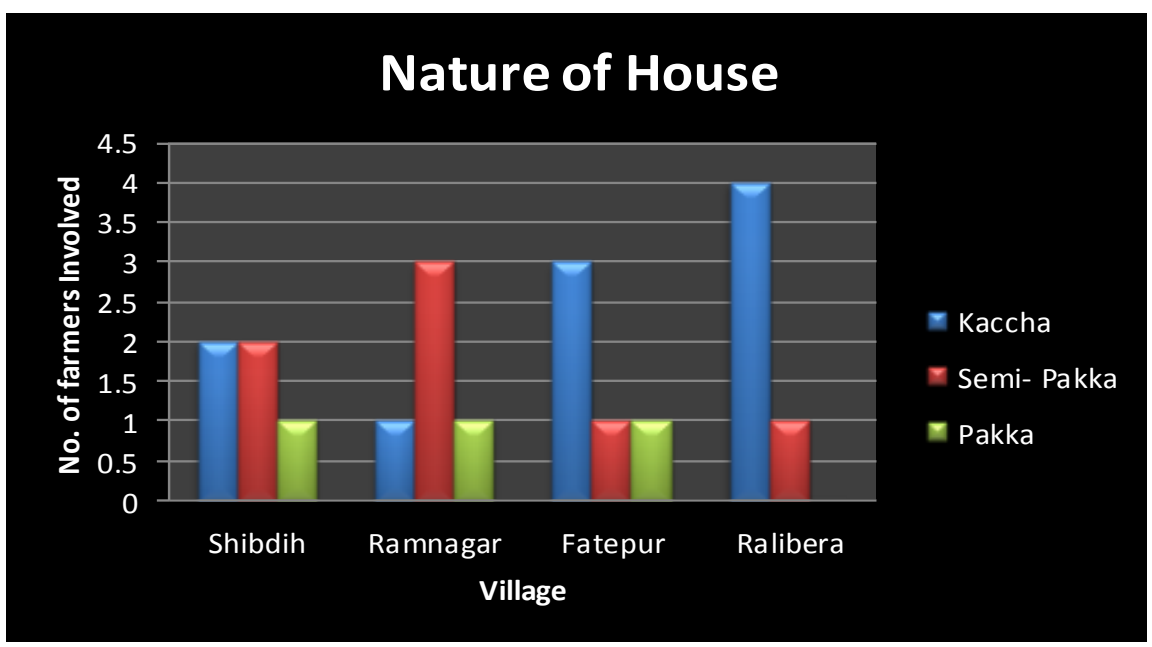

Fig.7 Nature of house 


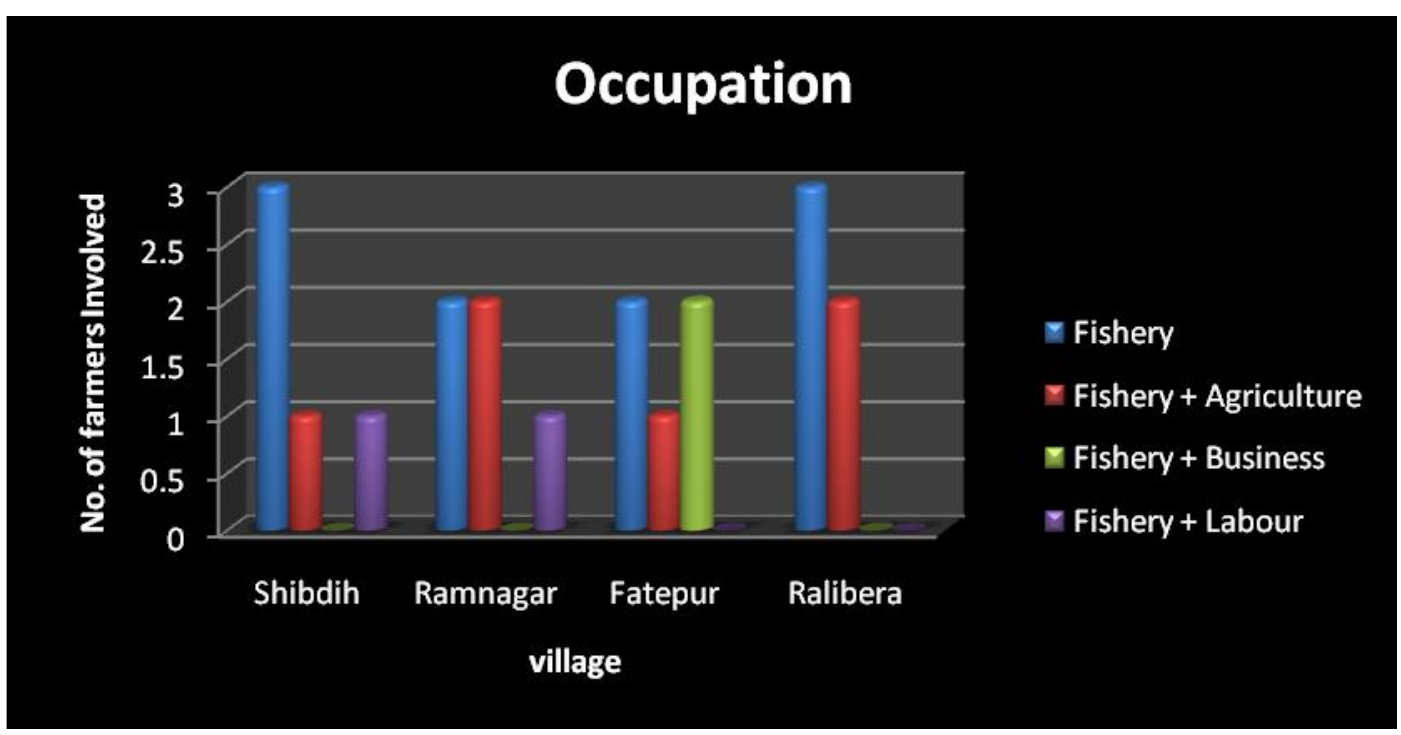

Fig.8 Occupation

Integrated fish farming is the blending of various compatible agricultural enterprises into a functional or unified farming system for the purpose of sustainability and it varies from one area to another in terms of production combination, rates and sizes. Women/youth being the most vibrant group of people are involves in this system. It plays very important role in many aspects of women/youth development and empowerment and more profitable than unitary system of farming as it ensures a spread of financial risk for its varied diversified nature in rearing fish, animals and crops; it has a capacity of making more food available thus enhancing food security. Besides, it provide employment, thus alleviating poverty and enhancing the economic status of the rural populace in India and reduce to the barest minimum the level of violence from disenchanted youth that is characteristic of the country in recent times. From the research work carried in the block of Purulia-I, it clearly shows a positive impact upon the culture and subsequently to the farmers. To be more specific the following schemes are mainly emphasized viz, economic upliftment of rural people through operation of integrated pisciculture development, socio-economic upliftment of fishefolk through operation of pisciculture development scheme etc. are in operation. Study also reveals that, fisheries represent a vital sector in the thrust Programme of West Bengal Government for rural development through production of fish and other ancillary activities thereby generating rural employment and improvement of socioeconomic status of the fishers who are the prime contributors of fisheries production. Fisheries sector embraces a large population of scheduled castes and scheduled tribes. Rehabilitation of scheduled castes and scheduled tribes families through fishery activities has become a major boon for upliftment of their economic status above poverty line.

\section{References}

Ayyappan S, Kumar K and Jena J K 1998 Integrated fish farming practices and potentials. Fishing chimes 18 (1): pp 15-18.

Edwards P, Pullin R S V and Gartmer J A 1988 Research and education for the development of integrated crop livestock fish farming system in the tropics. ICLARM study Review, pp 16, 53.

J Yaswanth Kumar, M S Chari and H K 
Vardia (2015) Effect of integrated fishduck farming on growth performance and economic efficiency of Indian major carps, Livestock Research for Rural Development, pp 1-7.

Majhi, A. (2016). Socio Economic Upliftment of Rural Fishermen through Integrated Duck cum Fish Farming in Purulia-I Block of Purulia District. PGDAEM Project Report. National
Institute of Agriculture Extension Management (MANAGE), Rajendranagar, Hyderabad.

Zira J.D., Ja'afaru A., Badejo. B.I, Ghumdia, A.A and Ali, M.E. (2015), Integrated fish farming and poverty alleviation/hunger eradication in Nigeria. IOSR Journal of Agriculture and Veterinary Science, Volume 8, Issue 6 Ver. I (Jun. 2015), pp 15-20

\section{How to cite this article:}

Abhishek Majhi. 2020. Socio Economic Upliftment of Rural Fishermen \& Poverty Alleviation through Integrated Duck Cum Fish Farming in Purulia District, West Bengal, India. Int.J.Curr.Microbiol.App.Sci. 9(06): 991-1001. doi: https://doi.org/10.20546/ijcmas.2020.906.124 